\title{
Vulnerable areas determination based on seismic response at Chile center region
}

\author{
Luciana das Dores de Jesus da Silva, PhD Candidate ${ }^{1, *}$, Mauricio Ivan Aguayo Arias, $\mathrm{PhD}^{2,}$, Priscila Nunes Muniz Barreto, \\ $\mathrm{MASc}^{3}$
}

${ }^{1}$ EULA Center, Urban Planning Department, EULA - Chile, Casilla 160-C, Chile

${ }^{2}$ EULA Center, Urban Planning Department, EULA - Chile, Casilla 160-C, Chile

${ }^{3}$ Braun Geotechnical, 19049 95A Avenue, Surrey, BC, Canada

\begin{abstract}
Chile is one of most seismic countries in the world. In the past 100 years, more than 8 major seismic events occurred in Chile, with the coastal area of central Chile being one of the most affected Since 2007, nearly 2,306 earthquakes were recorded in this area with magnitudes varying between 1.9 and 6.9 in the Ritcher and Mercalli scales. The earthquakes' impact on the engineering structures depends on several factors, such as: the depth of the wave, wave type, geomorphological aspects of the rock, and soil properties. Chile central region of is a very important economics area, but at the same time, very vulnerable. The cities existing on this area, are installed in coastal plains, limited by Coastal Mountains and Pacific Ocean. Most of the seismic activity episodes recorded by Nacional Seismological center (CSN) is on the ocean. The present research aims to identify the regions vulnerable to significant seismic activities based on the average shear wave velocity on the upper 30m (Vs30) and using Geographic Information Systems. The Vs30 values were measured by the United Stated Geological Service (USGS). This analysis is based on the topography, geological units classified by Chilean norms NCh433, NCh2369, and law decree 61/ 2011. The analysis indicated that last epicenter city, Cobquecura, is the low vulnerable area, considering high Vs30 values and low number of habitants. Cities as Concepción, Talcachuano, San Pedro de la Paz, Coronel y Hualpén are more vulnerable because low Vs30 values, and high population. This factor can be associated to river mouths and floodplains presents in this area.
\end{abstract}

\section{Introdution}

Chile is one of most seismic countries in the world, registering in 2017 a total of 8,094 earthquakes. The number of registered earthquakes increased by $26 \%$ from 2016 to 2017 , in which there were 6,437 tremors (for the entire territory), according to a report by the National Seismological Center (Centro Sismológico Nacional CSN) [1]. In the past 100 years, more than ten events of magnitude 8 or higher occurred in Chile [2].

An $8.8 \mathrm{Mw}$ earthquake with epicenter at Cobquecura in 2010 caused infrastructure damage mainly in coastal zone at central Chile [3] near the earthquake epicenter. In this area, the historical data recorded from 2006 to 2019 indicate increase in the number of daily small earthquakes (short period and magnitude less than $6.9 \mathrm{Mw}$ ) in the last thirteen years. After the 2010 event, the number of daily small earthquakes increased approximately 600 times in comparison to previous years. Ground motions amplified by surficial materials can exacerbate the situation, often making the difference between minor and major damage [4]

The seismic impact to the surface can be measured by the secondary wave velocity of propagation on the first 30 meters of surface. These values are related with capacity of wave propagation, expressed by material. The Vs30 is a parameter used to determine the ground susceptibility to loss of strength during an earthquake.

This research analyzed the Vs30 values of eleven cities, based on USGS data which were acquired by tectonic measurements. Mean, Maximum, Minimum and Majority Vs30 were calculated. The Vs30 values were mapped with number of seismic events, slopes, eroding zones, and population. Finally, all parameters were evaluated to determine municipalities more vulnerable to damage during or after a seismic event.

Chile lacks the inclusion of disaster risk management tools in its public policies at the community level [5]. Only the municipality of Talcahuano (one of the cities evaluated in this work) is recognized internationally for considering natural disasters problems $[6,7]$.

\subsection{Seismic wave propagation}

The release of tectonic energy occurs from the movement of tectonic plates, which generate seismic waves causing ground tremble. The waves radiate in all directions from the hypocenter.

The waves are classified into two types: primary wave (P-wave) and secondary wave (S-wave). P motion travels

\footnotetext{
* Corresponding author: lucisilva@udec.cl
} 
fastest in materials, so the P-wave is the first-arriving energy on a seismogram, and generally with smaller amplitude and higher frequency than the $\mathrm{S}$ and surface waves, respectively. S-waves travel slower than P-waves in a solid and, therefore, arrive after the P-wave. Usually the $\mathrm{S}$ wave has greater amplitude than the $\mathrm{P}$ and feels stronger than $\mathrm{P}$-waves [8].

The wave propagation intensity is felt depending on the rock geomorphological aspects. The Vs30 can be an indicator as a "proxy" to investigate seismic deformation. The Vs30 is average shear wave in the $30 \mathrm{~m}$ thick surface layer of the soil and/or rock. It is considered a trace of seismic behavior of foundation units floors before the seismic waves action generated by earthquake [9]. Chilean standards for building designs NCh433, NCh2609 and Decree 61/2011 have taken the VS30 as the design parameter for the seismic design of civil structures [10].

\subsection{Chilean building code NCh 433/ NCh 2639}

Chilean Seismic Standards NCh 433 (Seismic Design of Buildings) and NCh 2369 (Seismic Design of Industrial Structures and Facilities) were developed to reduce vulnerability of structures at seismic events. The first was created in 1996 and modified in 2008. The second was created in 2003 and is considered a more complete version than the NCh 433 because it incorporates the seismic design of industrial facilities. The NCh 433 is based on seismic events that occurred particularly in the years between 1960 and 1985 [11, 12].

These seismic regulations provide guidelines for civil construction, through the characterization by seismic parameters. The Chilean territory is classified into three seismic zones, being study area is in Zone 3 (Boundary of Biobio and Nuble regions, near to ocean). These zones represent characterized areas by geology, soils and geotechnical parameters.

The codes shall be applied in conjunction with the specific design standards for each construction material to achieve structures that: a) are able to resist seismic movements of moderate intensity without significant damage; b) limit damage to non-structural elements during medium intensity earthquakes; c) avoid collapse during earthquakes of exceptionally severe intensity. In addition to the type of construction, material aspects, soil type, topography and geomorphology are considered, which will dictate how the foundations of these structures will be impacted. That is, the seismic wave has different perceptions and impacts depending on the medium in which they propagate.

\section{Study area}

The coast of the Biobio and Nuble regions are one of the most important areas of Chile, due to their economic activities, location of ports and forestry industries. These regions are in the macro central region of Chile, in the "Gran Concepcion" area. The "Gran Concepcion area is the second most populated region of Chile [13]. The studied areas included the municipalities of Cobquecura,
Tomé, Penco, Talcahuano, Hualpén, Concepción, San Pedro de la Paz, Coronel, Lota, Arauco and Lebu (Figure 1). All studied areas are located on the coastal zone, where various disasters happened throughout history, mostly related to seismic activity.

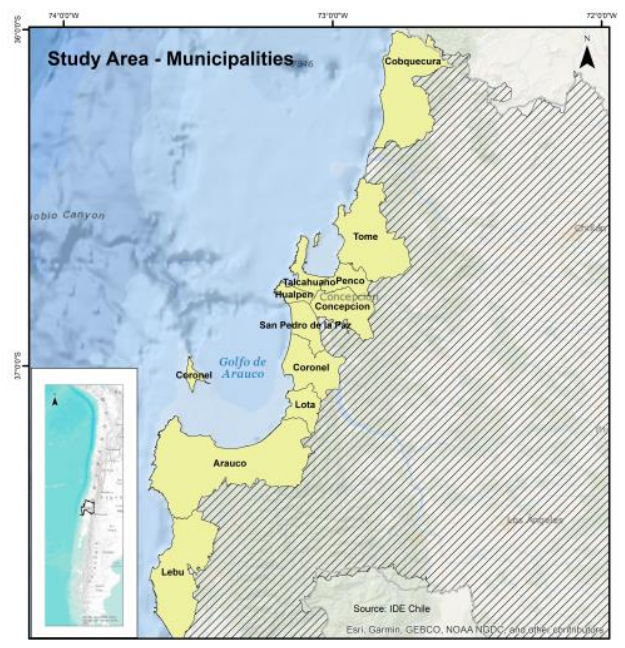

Fig. 1. Municipalities map; source: own elaboration based on IDE Chile

\subsection{Antecedents}

The municipalities located on the coastal edge arose without urban planning, affecting natural systems [14], occupying the coastal plain, product of erosion of the Mountain range of the Coast. Therefore, part of urban settlements is in slope areas. According to Figure 2, the coastal edge is occupied by the cities mentioned above, which have great erosive potential, where most of the area of these cities are classified based on geomorphology aspects as erosion potential [15]: very severe, severe and moderate. For instance, most of the Cobquecura area, the edge of Tomé, Talcahuano and Hualpén stand out for "very severe" erosive potentials (black color in map). Most of the area within the studied cities are classified as "severe" erosion potential (red color).

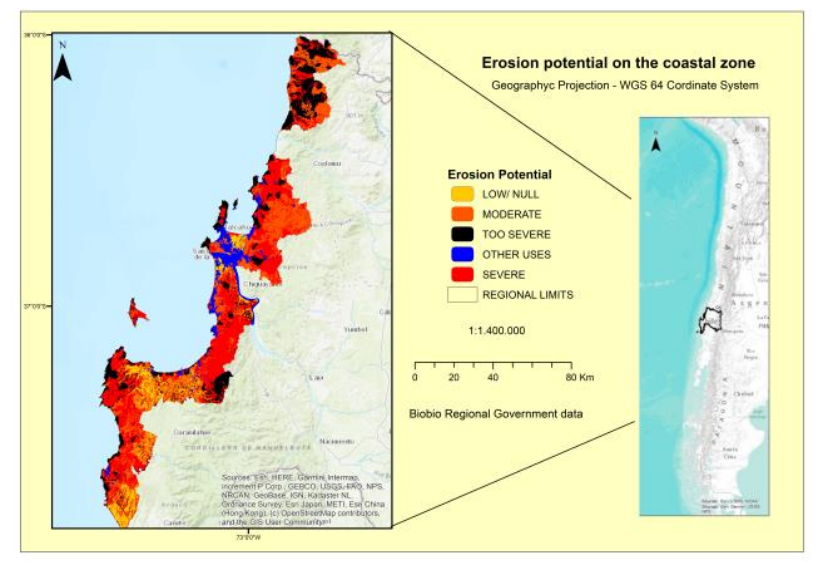

Fig. 2. Roding on the Biobío coast; source: own elaboration, based on Biobío regional government data. 


\subsection{Historical seismic situation}

In addition to the erosive potential, the studied municipalities have as a common factor to be located at a seismically active area. In 2010 there was a historical earthquake of $8.8 \mathrm{Mw}$, which affected more than 13 million people, which represents approximately $80 \%$ of the country's population [16]. The municipalities located in the vicinity of the epicenter, presented greater seismic impact than other regions, generating secondary events such as landslides and tsunamis [17]. Figure 3 shows the earthquakes with the greatest destructive capacities throughout history, note that they are located near to studied municipalities. Within the history, the most recent earthquakes occurred in the years 2010 and 2011 due to the damages generated, the Ministry of Housing and Urban Development published Decree of Law No. 61, in 2011. This Decree considers the use of the Vs30 [18].

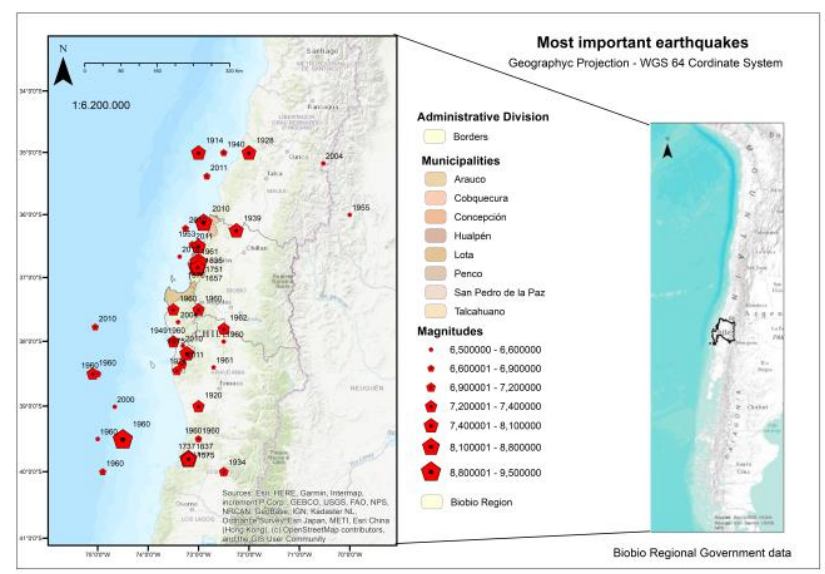

Fig. 3. Most important earthquakes of chile. source: own elaboration, based on centro sismologico nacional data.

As of 2006, Chile begins to record earthquakes of short duration and magnitudes since 2.0. Historical data will record 2,306 daily earthquakes, for this area in the last 12 years, measured on the Ritcher and Mercalli scales (taking as a reference a study area).

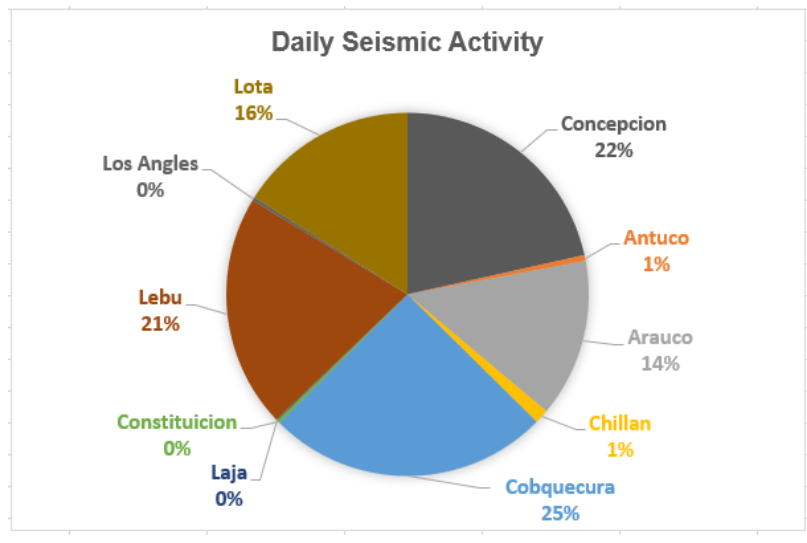

Fig. 4. Seismic daily percentage per municipality; source: own elaboration, based on centro sismologico nacional data.

Figure 4 shows that the most active municipalities are Concepción and Cobquecura with $25 \%$ and $22 \%$ of the measured seismic events, respectively, in relation to the other municipalities. This data considers the magnitudes between 2.0 and 6.9 registered in the period (Ricther and Mercalli Scales). It should be noted that the location of the seismic points was taken as a reference, some municipalities shown are not part of the studied area but belong to the region.

After the 2010 earthquake, it can be observed through Figure 5 that this coast was activated, registering for 2010 about 667 seisms accumulated, considering the study area as reference.

\section{Seisms $X$ Years}

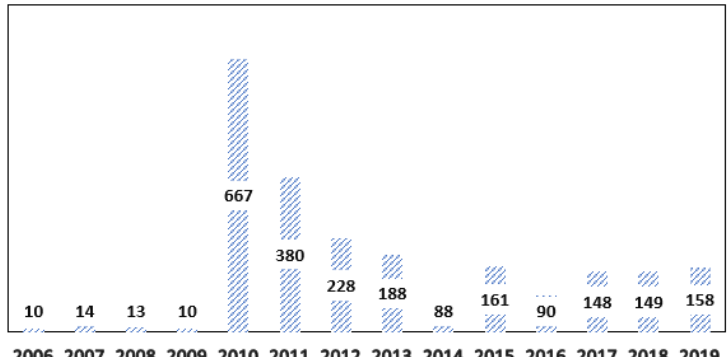

Fig. 5. Seisms quantity per year at study area; source: own elaboration based on centro sismologico nacional data.

The number of measured seismic events in 2011 were approximately half of the observed in 2010. The years 2014 and 2016 were the years with lesser records, after the 2010 great event. The number of seismic events increased after 2017, with 2019 being the most active since 2016 .

\subsection{Geomorphology}

The geological units of Chile are mainly composed of igneous, sedimentary, metamorphic and unconsolidated deposits of various origins, covering ages from the Ordovician to the Holocene. The islands of Chile are composed of volcanic rocks with specific sectors covered by unconsolidated deposits that form units of smallthickness soil. In general terms, the geology of continental Chile has been, and is, conditioned by location in a convergent margin of tectonic plates [19].The coastal boarder of the cities is located is structured in fault tectonics; the relief presents classic units of Central Chile. From West to East they follow sedimentary platforms and coastal plains. Coastal mountain range composed of granite and intensely weathered Paleozoic slates; the central depression in whose sine cones of Piedmont mainly fluviovolcanic and Andean, solid and volcanic mountain range are constituted [20].

The slopes of sun rocks ("solanas"), rocky, steep and heavily trafficked, have a high potential for erodibility. Particularly, they are threatened by the erosion of old terraces covered with trumao ("volcanics chilean soil, high porosity - Andosol"), raincoats that, under conditions of agricultural activities, increase this process on moderate slopes. [21]. Most of the urban centers located on coast are settled on coastal plain caused by 
sedimentation of the Cordillera de la Costa (Coastal Mountains).

\section{Seismic response}

The surface seismic response of a soil deposit and the seismic solicitation that develops on a structure located on a deposit are mainly dependent on: the stiffness at low deformations of the upper extracts of the foundation grounds, the fundamental period of the deposits of the soil, the level of damping developed by the different constituent soils of the land, and of the seismic disturbance (seismic activity) [22].

For the study area, the Vs30 raster was download from United States Seismological Service (USGS) web page, in a regular grid of 90-second arc cells, WGS 84 projection system The data relates $\mathrm{Vs} 30(\mathrm{~m} / \mathrm{s})$ and slope $(\mathrm{m} / \mathrm{m})$ for each Vs30 measurement point for data in active tectonic areas [23].

It was calculated the statistics per zone (Mean, Maximun, Majority and Minimun) for each city, using software Arcgis 10.1 version. After that, the soil/lithology composition was classified based on Vs30 values, proposed by Decree 61/2011.

Each information contained in the pixels was analyzed at the municipal level. This information gives: a) The capacity of wave propagation at zonal coast, represented by Vs30 map values; b) the soil composition based on statistical analysis per cities.

\section{Results}

The results indicate that, in general, the steepest slopes of the studied area have higher Vs30 values and lower Vs30 values may be encountered in the flat areas, as shown in Figure 6. According to the decree No. 61/2011encountered in both NCh433 and NCh2609 building codes, the soil profile is classified based on the soil shear wave velocity (Table 1 ).

Table 1. Vs30 classification based on decree 61/2011. source: self elaboration

\begin{tabular}{|c|c|}
\hline Soil Profile & Vs30 values $(\mathbf{m} / \mathbf{s})$ \\
\hline $\begin{array}{c}\text { A - Rock, cemented } \\
\text { ground }\end{array}$ & $\geq 900$ \\
\hline $\begin{array}{c}\text { B- soft or fractured } \\
\text { Rock / very dense or } \\
\text { firm ground }\end{array}$ & $\geq 500$ \\
\hline $\begin{array}{c}\text { C - Dense or firm } \\
\text { ground }\end{array}$ & $\geq 180$ \\
\hline $\begin{array}{c}\text { D - Moderately dense } \\
\text { or firm soil }\end{array}$ & $<180$ \\
\hline $\begin{array}{c}\text { E - soil of compactness } \\
\text { or medium consistency }\end{array}$ & \\
\hline
\end{tabular}

A first experiment overview relating the soil shear wave velocity and slope inclination is shown in Figure 6. Figure 6 indicates that for the Chilean topography, the
Slope's inclination and Vs30 are directly related. Regions with Vs30 values above approximately $600 \mathrm{~m} / \mathrm{s}$ overlaps the regions with steep slopes, in rocky outcrops. In the other hand, in flat areas near river mouths and floodplains, the measured Vs30 values were below $180 \mathrm{~m} / \mathrm{s}$. River mouths and floodplain areas generally comprises saturated loose to poorly compacted sands and soft to firm fine-grained soils. During a seismic event, these soils are susceptible to liquefaction and strength softening, respectively [24].

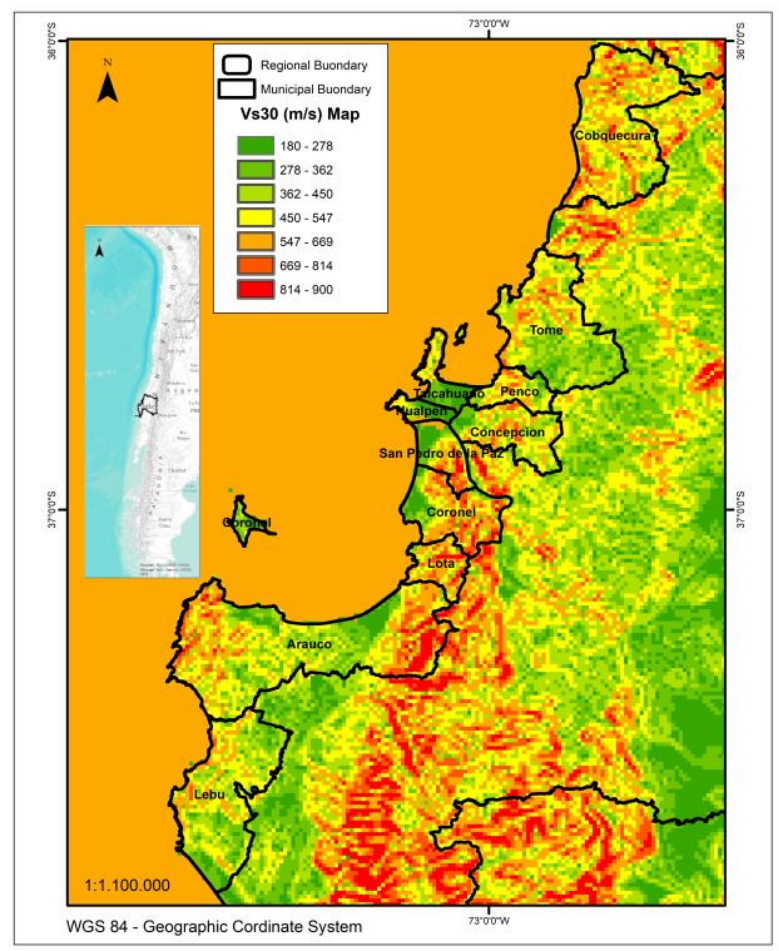

Fig. 6. Municipality Vs30 map. source: own elaboration based usgs model data.

Figure 7 and Table 2 present the Vs30 values mean, maximum, majority (most frequencies) and minimum values measured at different municipalities. The ground of each municipality was classified based on the values presented in Table 1.

Table 2. Vs30 by municipalities; source: own elaboration

\begin{tabular}{|c|c|c|c|c|}
\hline Municipality & Mean & Maximum & Majority & Minimum \\
\hline Cobquecura & $534 \mathrm{~m} / \mathrm{s}$ & $900 \mathrm{~m} / \mathrm{s}$ & $538 \mathrm{~m} / \mathrm{s}$ & $196 \mathrm{~m} / \mathrm{s}$ \\
\hline Tome & $443 \mathrm{~m} / \mathrm{s}$ & $815 \mathrm{~m} / \mathrm{s}$ & $363 \mathrm{~m} / \mathrm{s}$ & $196 \mathrm{~m} / \mathrm{s}$ \\
\hline Penco & $476 \mathrm{~m} / \mathrm{s}$ & $729 \mathrm{~m} / \mathrm{s}$ & $463 \mathrm{~m} / \mathrm{s}$ & $259 \mathrm{~m} / \mathrm{s}$ \\
\hline Talcahuano & $382 \mathrm{~m} / \mathrm{s}$ & $664 \mathrm{~m} / \mathrm{s}$ & $600 \mathrm{~m} / \mathrm{s}$ & $186 \mathrm{~m} / \mathrm{s}$ \\
\hline Hualpen & $398 \mathrm{~m} / \mathrm{s}$ & $610 \mathrm{~m} / \mathrm{s}$ & $600 \mathrm{~m} / \mathrm{s}$ & $181 \mathrm{~m} / \mathrm{s}$ \\
\hline Concepcion & $466 \mathrm{~m} / \mathrm{s}$ & $766 \mathrm{~m} /$ & $600 \mathrm{~m} / \mathrm{s}$ & $212 \mathrm{~m} / \mathrm{s}$ \\
\hline San Pedro & $499 \mathrm{~m} / \mathrm{s}$ & $900 \mathrm{~m} / \mathrm{s}$ & $600 \mathrm{~m} / \mathrm{s}$ & $207 \mathrm{~m} / \mathrm{s}$ \\
\hline Coronel & $515 \mathrm{~m} / \mathrm{s}$ & $900 \mathrm{~m} / \mathrm{s}$ & $600 \mathrm{~m} / \mathrm{s}$ & $182 \mathrm{~m} / \mathrm{s}$ \\
\hline Lota & $582 \mathrm{~m} / \mathrm{s}$ & $900 \mathrm{~m} / \mathrm{s}$ & $600 \mathrm{~m} / \mathrm{s}$ & $256 \mathrm{~m} / \mathrm{s}$ \\
\hline Arauco & $495 \mathrm{~m} / \mathrm{s}$ & $900 \mathrm{~m} / \mathrm{s}$ & $900 \mathrm{~m} / \mathrm{s}$ & $183 \mathrm{~m} / \mathrm{s}$ \\
\hline Lebu & $454 \mathrm{~m} / \mathrm{s}$ & $900 \mathrm{~m} / \mathrm{s}$ & $600 \mathrm{~m} / \mathrm{s}$ & $216 \mathrm{~m} / \mathrm{s}$ \\
\hline
\end{tabular}



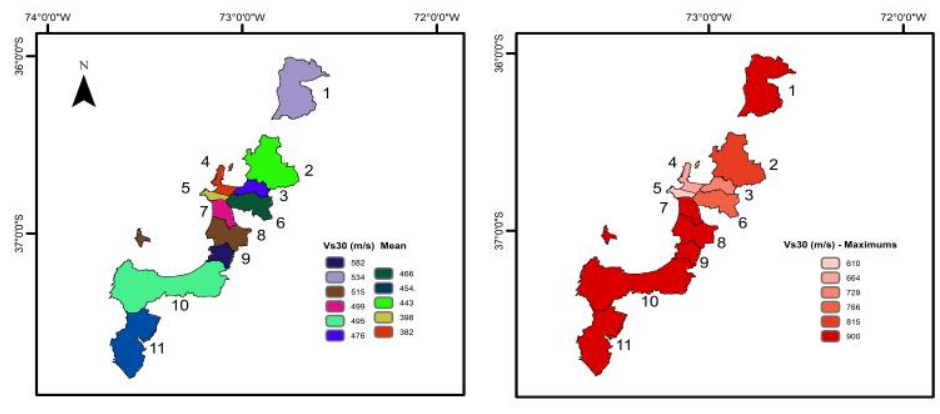

Vs $30(\mathrm{~m} / \mathrm{s})$ - Statistical Analysis
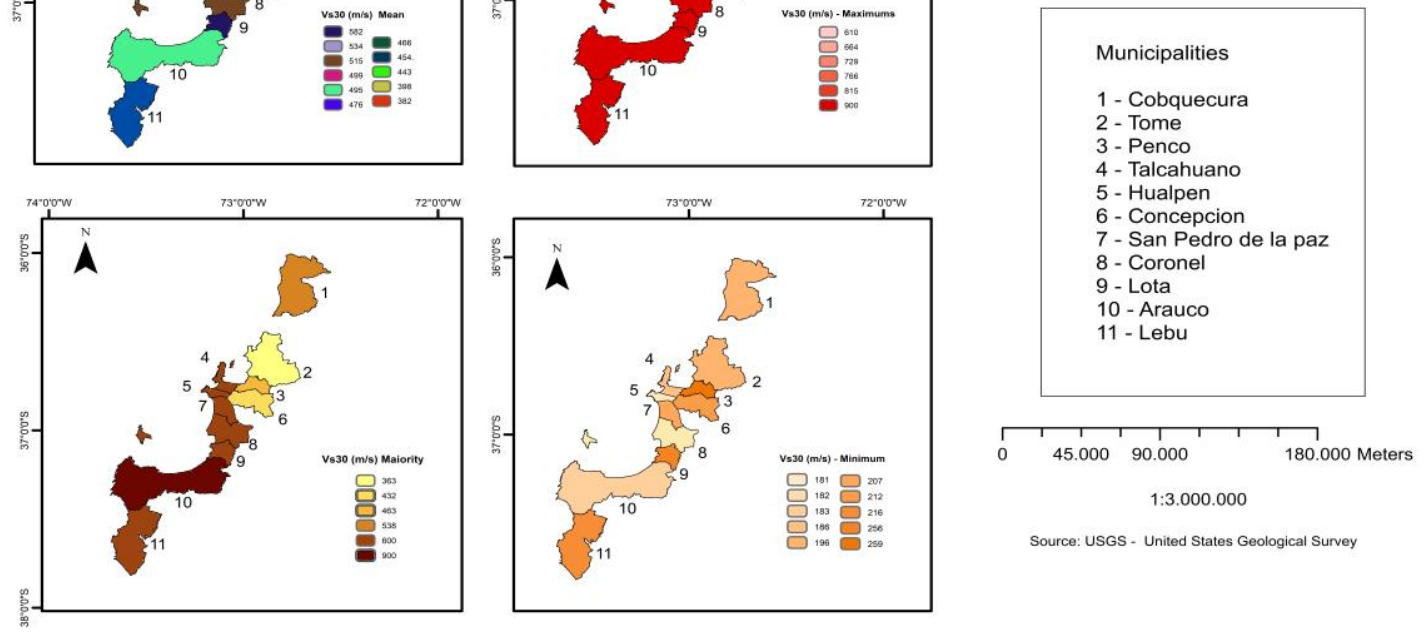

Fig. 7. Vs30 municipalities conditions Map. Source: Own elaboration based on USGS data analysis.

The highest mean shear wave velocities were measured in Lota and Cobquecura $582 \mathrm{~m} / \mathrm{s}$ and $534 \mathrm{~m} / \mathrm{s}$ respectively. Talcahuano has the lowest Vs30 value of $382 \mathrm{~m} / \mathrm{s}$.

According to Table 2, six municipalities have Maximum values of Vs30 of $900 \mathrm{~m} / \mathrm{s}$ : Cobquecura, San Pedro de la Paz, Coronel, Lota, Arauco and Lebu. The rock outcrops or cemented soils can comprise most steep slope areas. Tomé, Penco presents Rock and/or cemented ground characteristics, considering velocities near to 900 $\mathrm{m} / \mathrm{s}$. Talcachuano, Hualpen and Concepción presents features near to soft or fractured Rock to very dense or firm ground characteristics (By law 61/2011 class B).

The Maiority values indicates most frequencies and indicate how lithology conditions are more common. A generalized subsoil profile for each municipality based on available geological maps hole logs is as follows:

- Cobquecura: soft or fractured rocks / dense and very firm soils;

- Tomé dense and very firm soils;

- Penco soil profile comprises soft or fractured Rock / very dense or firm ground and dense or firm ground;

- Talcahuano, Hualpen, Concepción, San Pedro de la Paz, Coronel, Lota and Lebu present soft or fractured Rock / very dense or firm ground; Arauco presents Rock, cemented ground.

The minimum values presented at low areas located at Cobquecura, Tomé, Penco, Concepción, San Pedro de la Paz, Lota y Lebu, indicate the composition of firm and moderately dense soils. The municipalities of Hualpen, Talcahuano, Coronel and Arauco are classified by compacted or medium consistency soils, because the values are near to $180 \mathrm{~m} / \mathrm{s}$.

Vulnerability exists when there is a possibility of physical damage, material and exposed elements [25]. Therefore, to determine the most critical areas, the number of habitants affected by the possible disaster should be analyzed collectively with historical data, measured Vs30, and geotechnical and geological aspects. According to Table 3, the most populated municipalities are Concepción, Talcahuano, San Pedro de la Paz and Coronel [26].

Table 3. Habitants by Municipality. Source: Adaptaded Chilean Cities Statistical Reports (2017)

\begin{tabular}{|c|c|}
\hline Municipality & Population \\
\hline Concepcion & 223.574 \\
\hline Talcahuano & 163.623 \\
\hline San Pedro & 131.808 \\
\hline Coronel & 116.262 \\
\hline Hualpen & 91.773 \\
\hline Tome & 54.946 \\
\hline Penco & 51.611 \\
\hline Lota & 43.535 \\
\hline Arauco & 36.257 \\
\hline Lebu & 25.035 \\
\hline Cobquecura & 5.012 \\
\hline
\end{tabular}


The priority areas are Concepcion, Talcahuano, Hualpen, San Pedro de la Paz and Coronel, based on ground condition (Classified due Vs30 values), seismic historical data and number of habitants.

Although Cobquecura is the municipality with the highest amount of daily seismic activity and very severe erosive potential, the generally high Vs30 and low number of habitants suggest that this municipality has a low vulnerability to seismic damage.

The Cobquecura, Tomé, Talcahuano and Hualpen has severe erosive potential and $22 \%$ of the daily earthquakes that affect Concepcion also reach Hualpén, Talcahuano and San Pedro de la Paz due to the proximity between the three municipalities. These municipalities should consider disaster risk management in their public policies, since they meet the minimum requirements for disasters occurrences, may be a consequence of seismic activity, or they may cause other secondary disasters such as landslides, tsunamis and floods.

\section{Conclusions}

The Vs30 is the average shear wave velocity of the material encountered below ground level. This parameter combined with historical earthquake data and the number of habitants in a region may be considered to determine the vulnerable zones to seismic damage. Evaluating these parameters in a small scale allows the determination of priority zones and may help on the municipality's decision-making process.

The most vulnerable municipalities are Concepción, Talcahuano, San Pedro de la Paz, Coronel and Hualpen, considering the majority and minimum Vs30 values and number of habitants.

Zones with low Vs30 values are more susceptible to loss of strength during an earthquake. The soil loss of strength, also called soil liquefaction for cohesionless soils, may result in severe settlement of structures, landslides, and other hazards. The minimum Vs30 values designate which areas had a concerning seismic response. This factor may occur due to proximity of this areas to water bodies as well as bordering and mouth of the rivers and floodplains. A next step of this research would be to understand the dynamics of the earthquake phenomenon, the analysis of precipitation pattern, and in situ experiments for the determination of the soil and rock strength parameters, to demonstrate more precisely the influence of the earthquake phenomenon on the landslides occurring on the coastal zones of Chile.

The authors would like to thank the UCO Project 1866, which allowed the publication of this article. The first author acknowledges the department of urban planning for logistically supporting this research.

\section{References}

1. Efe Noticias. Chile uno de los paises mas sísmicos del mundo. Avaiable <http://www.diarioeldia.cl/mundo/chile-es-paises- mas-sísmicos-mundo-con-8094-temblores-en-2017> Acessed 3th January.

2. S. Beck, S. Barrientos, E. Kausel, M. Reyes, Source characteristics of historic earthquakes along central Chile subduction zone Jour. (South Am. Earth Sc. 11 (2) doi:10.12/S0895-9811(98)00005-4 1998).

3. Relatorio Sismologico - (Centro Sismológico Nacional. Facultad de Ciencias Físificas y Matemátcas de Chile. (2019)

4. F. Arenas, M. Lagos, Y. R. Hidalgo, Los riesgos naturales en la planificación territorial planificación territorial. (2010)

5. K. Engel. Talcahuano, Chile, in the wake of the 2010 disaster: A vulnerable middle? Nat. Hazards 80:1057-1081 (2016)

6. J. Leon, A. March. Urban morphology as a tool for supporting tsunami rapid resilience: A case study of Talcahuano, Chile. Habitat International 43: 250-262 (2014).

7. Wave Types, British Geological Survey. Avaiable < https://www.bgs.ac.uk/discoveringGeology/hazards/e arthquakes/seismicWaves.html > Acess 3th January 2020.

8. R. Rauld, F. Medina, F. Leyton, S. Ruiz, \& V. Mar. Mapa de microzonificación sismo-geológica para Chile., 106-109 (2015).

9. República de Chile. 'Aprueba reglamento que fija el diseño sísmico de edificios y deroga Decreto $\mathrm{N}^{\circ} 117$, de 2010,' Diario Oficial de la República de Chile, Cuerpo I, 8-12 (2011).

10. INN. Diseño Sísmico de Edificios, Norma Chilena Oficial NCh433.Of1996 (Modificada en 2009), Instituto Nacional de Normalización, Santiago, Chile (2a edición 2009).

11. INN. Diseño Sísmico de Estructuras e Instalaciones Industriales, Norma Chilena Oficial $\mathrm{NCh}$ 2369.Of2003, Instituto Nacional de Normalización, Santiago, Chile (2003)

12. Reportes comunales. Avaiable in <https://reportescomunales.bcn.cl/2017/index.php/Ca tegor\%C3\%ADa:Comunas> Acessed 2th January 2020

13. E. S. Varela, L. P. Bustamante. Procesos urbanos recientes en el Área Metropolitana de Concepción: transformaciones morfológicas y tipologías de ocupación. Revista de Geografia Norte Grande. (2011)

14. Potencial de Erosion. Datos del Gobierno de la Region del Biobio. Available in $<$ http://sriit.gorebiobio.cl/ >.

15. M. Mardones, \& C. Vidal. La zonificación y evaluación de los riesgos naturales de tipo geomorfológico: un instrumento para la planificación urbana en la ciudad de Concepción. EURE (Santiago), 27(81), 97-122. https://doi.org/10.4067/S0250-71612001008100006 (2001)

16. M. Mardones, \& C. Vidal. La zonificación y evaluación de los riesgos naturales de tipo 
geomorfológico: un instrumento para la planificación urbana en la ciudad de Concepción. EURE (Santiago), 27(81), 97-122. https://doi.org/10.4067/S0250-71612001008100006 (2001)

17. Decreto 61/2011. Reglamento de Fija el diseno sísmico de edificios. Ministerio de Vivienda y Urbanismo. (2011)

18. R. Rauld, F. Medina, F. Leyton, S. Ruiz, \& V. Mar. Mapa de microzonificación sismo-geológica para Chile., 106-109 (2015).

19. Geografia de Chile. Instituto Geografico Militar. I.S.B.N. 956-202-060-3. Primera Edición. 57, 84 p. (2001)

20. Decreto 61/2011. Reglamento de Fija el diseno sísmico de edificios. Ministerio de Vivienda y Urbanismo. (2011)

21. Geografia de Chile. Instituto Geografico Militar. I.S.B.N. 956-202-060-3. Primera Edición. 57, 84 p. (2001)
22. T.I. Allen, and D.J. Wald, Topographic slope as a proxy for global seismic site conditions (VS30) and amplification around the globe: U.S. Geological Survey Open-File Report 2007-1357, 69 p. (2007)

23. Lawson, A. (Editor). The California Earthquake of April 18, 1906: Report of the State Earthquake Investigation Commission, Carnegie Institution of Washington, Washington, D.C. (1908)

24. Chowdhury, P. A. R.. Landslide hazard assessment: summary review and new perspectives, 21-44. (1999)

25. Reportes comunales. Avaiable in <https://reportescomunales.bcn.cl/2017/index.php/Ca tegor\%C3\%ADa:Comunas> Acessed 2th January 2020.

26. Reportes comunales. Avaiable in <https://reportescomunales.bcn.cl/2017/index.php/Ca tegor\%C3\%ADa:Comunas $>$ Acessed 2th January 2020 